\title{
EFFECT OF SUBCULTURE FREQUENCY TOWARD GROWTH AND CAROTENOID CONTENT FROM TOMATO (Lycopersicon esculentum Mill.) CALLUS
}

\author{
Reni Indriani $^{1 *}$, Erma Prihastanti ${ }^{2}$, Rini Budihastuti ${ }^{3}$, Yulita Nurchayati ${ }^{4}$
}

\author{
Received : September 10, 2019 \\ Accepted : September 27, 2020 \\ DOI: 10.15575/biodjati.v5i2.5840
}

1,2,3,4 Department of Biology, Faculty of Science and Mathematics, Universitas Dipenogoro

Jl. Prof. H. Soedharto, SH. Tembalang Semarang 50275; Telephone (024) 7474754 .

e-mail:

*1reniindriani51@gmail.com

eprihast@yahoo.co.id

3rini_puryono@yahoo.com

4yulita.yoko@gmail.com

*Corresponding author

\begin{abstract}
Tomatoes (Lycopersicon esculentum Mill.) are a source of carotenoids they are easy to find. These compounds function as precursors of vitamin A, antioxidant, and prevent cancer. The extraction of carotenoid compounds for commercial products usually uses fresh plants, which are less efficient and require a lot of raw materials. The supply of these raw materials can be done through tissue culture. The frequency of subculture or supply of nutrients in tissue culture is very influential on the content of callus carotenoids produced. This study aimed to determine the effect of subculture frequency on growth, development and callus carotenoid content and to find out the right frequency of subculture to produce callus with optimal growth, development and carotenoid content. This study was a single Completely Randomized Design (CRD) with four treatments of subculture frequency and five replications. The data obtained were analyzed by ANOVA at the 95\% test level followed by $D M R T$ in case a significant different was found The results showed subculture frequency affected growth, development and carotenoid content of callus Lycopersicon esculentum. Mill. The most optimal treatment to induce growth and production of carotenoids in this study was treatment of thrice subculture while the most optimal treatment in inducing development was the twice subculture treatment.
\end{abstract}

Keywords: callus, carotenoids, hypocotyl, Lycopersicon esculentum Mill., subculture

\section{Citation}

Indriani, R., Prihastanti, E., Budihastuti, R. \& Nurchayati, Y. (2020). Effect of Subculture Frequency Toward Growth and Carotenoid Content from Tomato (Lycopersicon esculentum Mill.) Callus. Jurnal Biodjati, 5(2), 303-315.

\section{INTRODUCTION}

Plant tissue culture is a technique of isolating plant parts such as protoplasts, cells, tissues, and organs which are then grown in artificial media in an aseptic environment. Tissue culture techniques can be used for propagation, plant breeding, and secondary metabolite production (Osman et al., 2012). Tissue culture techniques in growing explants can be done with several techniques, namely meristem culture, anther culture, embryo culture, protoplast culture, chloroplast culture, pollen culture, and callus culture (Olusegun et al., 2012).

Callus culture is a tissue culture technique using explants in the form of callus. A callus is an irregular proliferation of cell mass that has not been differentiated (Ikeuchi 


\section{JURNAL BIDDJATI}

http://journal.uinsgd.ac.id/index.php/biodjati

et al., 2013). The use of callus culture is to propagate theplants and produce secondary metabolic compounds (Baldi \& Dixit, 2008) including saponins (Ikhtimami, 2012), artemisinin (Purnamaningsih \& Ashrina, 2011), menthol, anethole, and estragole (Setyorini, 2018) as well as antioxidant compounds such as vitamin $\mathrm{C}$ and carotenoid (Noviati, 2014).

Carotenoids are found in brightly colored fruits such as tomatoes. Carotenoids play a role as a precursor of vitamin A, an antioxidant compound that can counteract free radicals so that it can be potentially developed in the health field (Ravi et al., 2010). Production of carotenoid compounds is usually conducted by extracting directly from fresh plant parts (Maleta et al., 2018). This method is less efficient as it requires a long time and a lot of biomass to get the fruit ready for extraction, while improper storage of tomatoes can reduce carotenoid levels (Javanmardi \& Kubota, 2006). To overcome the problem of carotenoid sources in fruits, effective and efficient methods can be used to produce these compounds.

The growth, development and production of carotenoid compounds can be done by in vitro culture methods. One of the stages of in vitro culture is a subculture which is the transfer of cells, tissues or organs from old media to new media, whether the media is the same or has a different composition from the original media, with the aim of gaining new growth or developmental power from the inoculum (Olusegun et al., 2012). Subcultures are stopped when undesirable morphological changes occur, characterized by browning, losing the ability to regenerate shoots and produce plants that are different from parent plants (Krishna et al., 2016).

The frequency of subcultures performed is adjusted by the type of plant used. Recommended subculture at most 3-6 times
(Hegazi et al., 2014). The callus of Talinum paniculatum Gaertn. without subcultured has less biomass but has higher saponin levels compared to the treatment of the 2-week subculture period (Ikhtimami, 2012), subculture once every 4-6 weeks in the conjoined orange callus ha not reduced the ability of callus proliferation (Wulansari et al., 2015). This research used explants from hypocotyl tomato sprouts, because according to Naghmouchi et al. (2008) the young plant parts more easily grows into a callus. Juvenile tissue has a high rate of cell division, thus young tissue is a good explant material. There is limited information about the influence of the number of subcultures on in vitro tomato culture. Therefore the aim of the research was to study the effect of subculture frequency on growth, development, and production of the highest carotenoids on tomato callus.

\section{MATERIALS AND METHODS}

\section{Plant Materials}

The research was conducted at the Plant Tissue Culture Laboratory, Department of Biology, Faculty of Science and Mathematics, Universitas Diponegoro from June-September 2019. Plant material used was tomato seeds of 'Panah Merah' production germinated aseptically grown on sterile cotton media. This starting material was incubated at laboratory temperature $\left(25^{\circ} \mathrm{C}\right)$, under light of 500 lux.

\section{Preparation of Explants and Callus Induct- ion}

Hypocotyl of tomatoes (Lycopersicon esculentum Mill.) sprout was used as explant which was taken from aseptic tomato sprouts aged seven days. The hypocotyl was cut into $1 \mathrm{~cm}$ long then weighed and planted in MS media with the addition of 1 ppm NAA and 1 ppm BAP (Ulva et al, 2019). 


\section{JURNAL BIDDJATI}

http://journal.uinsgd.ac.id/index.php/biodjati

\section{Subculture Treatment}

Subculture was carried out after the callus reached 20 days old and continued with the next subculture every 10 days by transferring the callus to new media. The 50 days old calluses from each treatment were then taken for analysis.

The study design used was a single Completely Randomized Design (CRD) with four treatments, based on subculture frequency as follows:

P0: Treatment without subculture

P1: Subcultured once

P2: Subcultured twice

P3: Subcultured three times

The parameters observed were callus initiation time, fresh weight, callus carotenoid content, color, texture, and callus development

\section{Statistical Analysis}

The experiments were carried out in five replications. The mean values with standard deviation (SD) were shown in the table and figures in the next section. The results were derived from statistical analysis using analysis of variance (ANOVA). Levels of significance were indicated by Duncan multiple range test at $\mathrm{P}<0.05$.

\section{RESULTS AND DISCUSSION}

\section{Callus Initiation}

The results from the effect of subculture frequency on growth and development of tomato (Lycopersicon esculentum Mill.) Permata F1 varieties hypocotyl callus are shown in Table 1. Callus initiation indicates the first response of explant to medium. The cells of the explants attached to the surface of the medium will absorb the nutrients inside and are used to grow. The process of dedifferentiation could be formed with auxin and cytokinin in the right concentration ratio (Rivai et al., 2014; Sugiyarto \& Kuswandi, 2014).

Table 1. Mean initiation time and the fresh weight of callus

\begin{tabular}{ccc}
\hline Treatment & Callus Initiation Time (DAP) & Fresh weight $(\mathrm{g})$ \\
\hline P0 & 6 & $3.22^{\mathrm{b}}$ \\
P1 & 6.7 & $4.09^{\mathrm{b}}$ \\
P2 & 6.7 & $5.12^{\mathrm{b}}$ \\
P3 & 6 & $9.21^{\mathrm{a}}$ \\
\hline
\end{tabular}

The numbers followed by the same letters in the same column show no significant difference based on Duncan's test at the 95\% significance level. DAP (Day After Planting

The results of callus initiation in this study ranged from days 6-8. All parts of the explant enlarged and wrinkled at 7 days after initiation. Primary callus was emerged from each side of cuttings, followed by the middle part of the explant after 10 days of incubation. When the appearance of callus is calculated in units of days after planting (DAP). The time of callus emergence in this study was relatively similar among treatment, because callus initiation occurred before the subculture treat- ment was imposed on planted explants. Callus initiation is characterized by swelling in parts that have direct contact with the media such as the hypocotyl tip and the wound site, this indicates that the explant responds to the media and absorbs the nutrients provided.

The hypocotyl is easier to be induced into callus when the growth requirements have been available. Besides nutrients from MS media, hormones are one of the triggers for callus induction. Here, the growth 


\section{JURNAL BIDDJATI}

http://journal.uinsgd.ac.id/index.php/biodjati

regulators used were 1 ppm NAA combined by $1 \mathrm{ppm}$ BAP. It showed suitable to induce the callogenesis of tomato sprout. According to Sari et al. (2014) callus induction caused by cuts or explant slices in response to hormones both exogenously and endogenously. Moreover, Mohajer et al. (2012) reported that plant growth regulator combination of auxin and cytokinin were needed for callus formation.

\section{The Fresh Weight of Callus}

Callus growth was marked by their weight. It showed that the concentration of 1 ppm NAA with 1 ppm of BAP was the optimal concentration in the formation callus of tomato sprout. As stated by Shah \& George (2019), the combination of auxin and cytokinin produces a better callus induction and biomass than adding only one growth regulator. The highest fresh weight was found in the subculture treatment three times $(9.21$ g) and the lowest weight was found in the treatment without subculture with a mean weight of $3.22 \mathrm{~g}$ (Table 1).

The increase in fresh weight was directly proportional to the number of subculture treatments performed. The average final callus weight was then analyzed using variance (ANOVA) and produced significantly different data with a significance value of 0.002 $(\mathrm{P}<0.05)$. It means that the frequency of subculture treatment significantly affected the growth of tomato callus. The data was further analyzed using the Duncan test to find out the most optimal treatment. Duncan's test results showed that the subculture treatment 3 times was optimal in increasing the growth of tomato callus.

Weight gain is a characteristic of growth, so measurements of initial weight and final weight can represent tomato callus growth variables. This research showed that subculture influences callus growth, where the subculture provides nutrition for callus on a regular basis. According to Karyanti et al. (2014) callus growth rate is influenced by the process of absorption of nutrients from the balanced medium with a regular supply of nutrients so that the media does not run out of nutrients. Therefore, to accelerate cell growth, it is necessary to do subculture at two or four weeks time intervals.

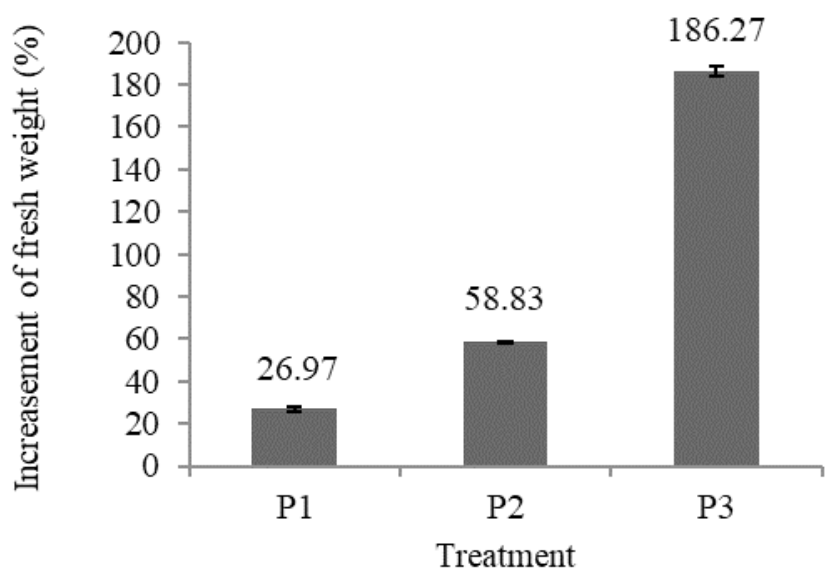

Figure 1. Percentage of increasement in fresh weight of callus 


\section{JURNAL BIDDJATI}

http://journal.uinsgd.ac.id/index.php/biodjati

These results indicated that subcultures support cell division, cell enlargement and cell differentiation through nutrients and hormones provided for callus. According to Grzyb et al. (2017), growth and morphogenesis in vitro are influenced by interactions and ratios between growth regulators which are added in the media, and hormones which are produced endogenously by cultured cells.

According to Majda \& Robert (2018), auxin can change the activity of enzymes that play a role in the synthesis of cell wall components and rearrange them in an intact cell wall matrix so that it will affect cell weight. Auxin can encourage cell elongation followed by cell enlargement and increasing the fresh weight. The increase in fresh weight was mainly due to the increased absorption of water by these cells. Whereas cytokinins are hormones that get involved in cell division. This is supported by Lipavská et al. (2011) which stated that in the $\mathrm{G} 2$ phase of cell division, cytokinins induce cyclin-dependent protein kinase (CDKs) which play a role in gene transcription at the stage of DNA replication. Furthermore, cytokines got involve in the activation of the enzyme phosphatase to reduce phosphate. Low phosphate can inhibit the protein CDKs toward the mitosis phase (M) cell division, thus cytokinins can accelerate the $\mathrm{G} 2$ phase in cell division. Sitinjak et al. (2016) stated that both auxin and cytokinins will be synergized in the cell divisions, ratio of them can drive the morphogenesis of explant. If the availability of cytokinins in the culture medium is very limited, cell division in the cultured tissue will be inhibited.

\section{Carotenoid Content}

Carotenoids are secondary metabolite compounds synthesized by plants. These compound can usually be found in almost all organs of plants such as leaves, stems, tubers, flowers, and fruits. Carotenoids are color pigments in plants and accumulate in plastids. In this study, carotenoid compounds were extracted from callus derived from hypocotyl explants.

Table 2. The carotenoid content in callus by different subculture frequency

\begin{tabular}{cc}
\hline Treatment & Carotenoid contents $(\mathrm{mg} / \mathrm{L})$ \\
\hline P0 & $113.32^{\mathrm{a}}$ \\
P1 & $126.75^{\mathrm{a}}$ \\
P2 & $124.32^{\mathrm{a}}$ \\
P3 & $132.34^{\mathrm{a}}$ \\
\hline
\end{tabular}

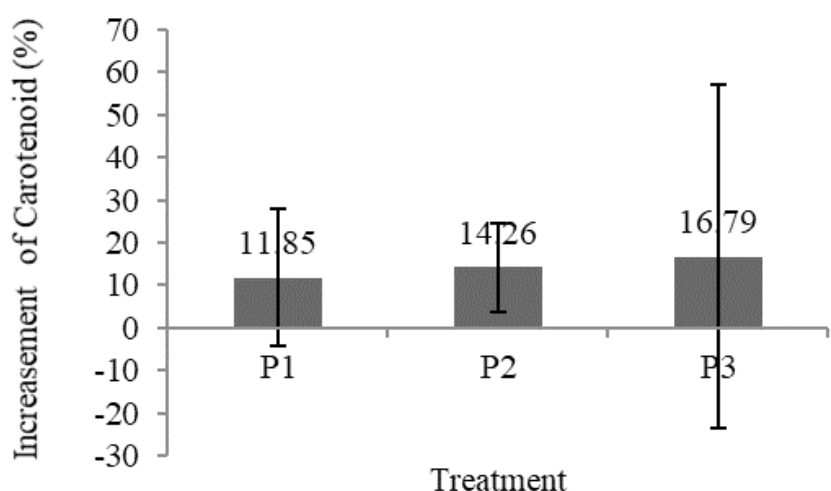

Figure 2. The increasement of carotenoid content from subculture treatments to the control 


\section{JURNAL BIDDJATI}

http://journal.uinsgd.ac.id/index.php/biodjati

Based on the analysis of variance in the frequency of subcultures, there was no significant effect on the carotenoid content of the hypocotyl callus Lycopersicon esculentum Mill. The data shows that even though there is an increasement in carotenoid production in the callus, the number is not significant. The highest percentage increase in carotenoid production compared to control was found in the P3 by $16.79 \%$ followed by P2 (14.26\%) and P1 (11.85\%).

The results of this study indicated that there is a possibility that carotenoid production will continue to increase in the next subculture. Because the carotenoid production still increased after the $3^{\text {rd }}$ subculture. Data on increased carotenoid content showed that the frequency subcultures (once, twice, and three times) were greater than control (without subculture). The carotenoid content which was almost the same in each treatment shows that the callus still in an exponential growth phase. In this phase, the callus was still in the stage of cell division and enlargement as evidenced by an increase in callus cell volume and microscopic cells (Figure 3.) so that carotenoid synthesis was not optimal. The callus consists of parenchyma cells that have a high rate of cell division (Figure 4). It was seen from the big nuclei in cells. According to Orbán et al.
(2008), secondary metabolites generally increase at the end of the exponential phase to the stationary growth phase. This opinion is assumed due to an increase in vacuoles and cell plastids.

Besides that, the increase in carotenoid content which was not significant to the subculture treatment is thought to be caused by another factor that more influential than nutritional addition. It suspected that the light intensity is this factor. Here, light from the lamp (500 lux) was unable to stimulate an increase in the carotenoid content in tomato callus. Norshazila et al. (2017) reported that light and increment of MS salt concentration will trigger some carotenoids content $(\beta-$ carotene, zeaxanthin, and $\alpha$-carotene accumulation), PEG in light condition will only accumulate $\beta$-carotene of sweet potatoes callus. This PEG (Polyethylene glycol) is a chemical substance commonly used for drought tests on culture medium.

The qualitative data observed included callus color, callus texture and callus development marked by the appearance of roots and shoots. The results of this study were obtained through visual observation from the beginning of planting until the callus was 50 days old (Table 3).

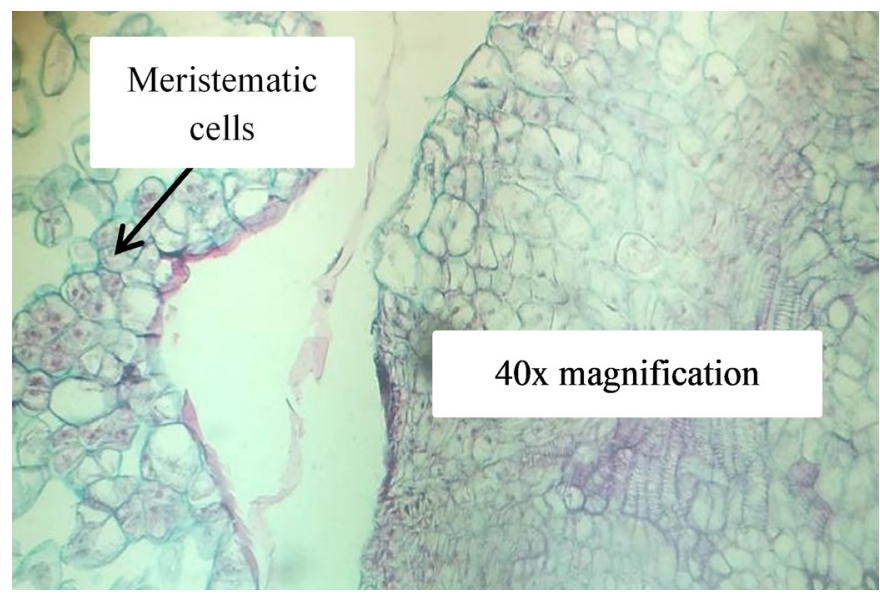

Figure 3. Cell of callus are still dividing 


\section{JURNAL BIDDJATI}

http://journal.uinsgd.ac.id/index.php/biodjati

Table 3. Color, texture, and development of callus Lycopersicon esculentum Mill. based on the treatment of subculture frequency after 50 days Callus

\begin{tabular}{ccccc}
\hline Treatment & Color & Texture & \multicolumn{2}{c}{ Development } \\
\hline & & & $\begin{array}{c}\text { Root } \\
\text { (strand) }\end{array}$ & $\begin{array}{c}\text { Shoot } \\
\text { (piece) }\end{array}$ \\
\hline Without subculture & Yellow greenish & Non friable & 1 & - \\
Once Subculture & yellowish white & Non friable & 2 & - \\
Twice Subculture & yellowish green & Non friable & 10 & 1 \\
Thrice Subculture & Yellow greenish & Non friable & 8 & 1 \\
\hline
\end{tabular}

\section{Texture of Callus}

Callus texture is one indicator to assess the quality of a callus. Maemunah et al. (2019) stated the callus with crumb texture (friable) of cells easily separated into single cells in suspension culture. Callus texture produced based the subculture frequency treatment (Table 2). The callus texture based on all treatment wasin compact type, meaning that the frequency of the subculture did not affect the callus texture of the hypocotyl explant of tomatoes. The callus crumbs of the bonds between cells appeared tenuous, easily separated and if taken with tweezers, the callus broke easily and was attached to the tweezers. Asmono \& Sari (2016) asserted that the watery friable texture on potato callus caused by auxin that increases the elasticity of cell walls. However, the compact callus has a texture that visually looks solid, difficult to separate, and has a hard structure. Moreover, variation in callus induction on different concentrations of growth regulators depends on the morphogenetic response which varies according to spatial and temporal cell distributions, and on physiological and developmental stages. Even there were the nodules in compact callus of Tagetes erecta from 2,4 D effect in medium Benítez-García et al. (2014) and Ming et al. (2019).

According to Benítez-García et al. Jurnal Biodjati 5(2):303-315, November 2020
(2014) and Maemunah et al. (2019), the formation of compact textured callus is driven by the presence of endogenous auxin hormones that are produced internally by explants that have grown to form callus as well as giving growth regulators from the medium. The added PGR can cause changes in plant physiology and biochemistry through the regulation of enzymes. Growth hormone plays a role in binding protein membranes that have the potential for enzyme activity. The results of this binding activate enzymes and change the substrate into several new products. The new product formed causes a series of secondary reactions, one of which is the formation of roots, shoots and, secondary metabolites.

\section{Callus Color}

The growth indicator of explants in vitro culture in the form of callus color illustrates the visual appearance of the callus so that it can be seen the morphology of cells that are actively dividing or have died. Callus tissue resulting from an explant usually brings up different colors. Color in cells or tissues shows the development of pigments and plastids in the living cells. The color of the callus indicates the pigment content.

The color of the callus produced based on the subculture frequency treatment (Fig- 


\section{JURNAL BIDDJATI}

http://journal.uinsgd.ac.id/index.php/biodjati

ure 4). The treatment without subculture produced a greenish-yellow callus, the treatment ofsubculture once produced a yellowish-white callus, the subculture twice produced a yellowish-green callus, and the subculture treatment thrice produced a greenish-yellow callus. The color of the yellowish green callus shows the callus in good condition. According to Hariyati et al. (2016) that callus color was one indicator of callus quality. The green callus shows the formation of chlorophyll. Sugiyarto \& Kuswandi (2014) and Sari et al. (2019), stated that the green color of callus is a result of the cytokinins (BAP) influence in the formation of chlorophyll. Callus tissue produced from an explant usually brings different colors. Callus color differences can be caused by several things including pigmentation, light intensity, and explant sources from different plant parts (Sari et al., 2014).
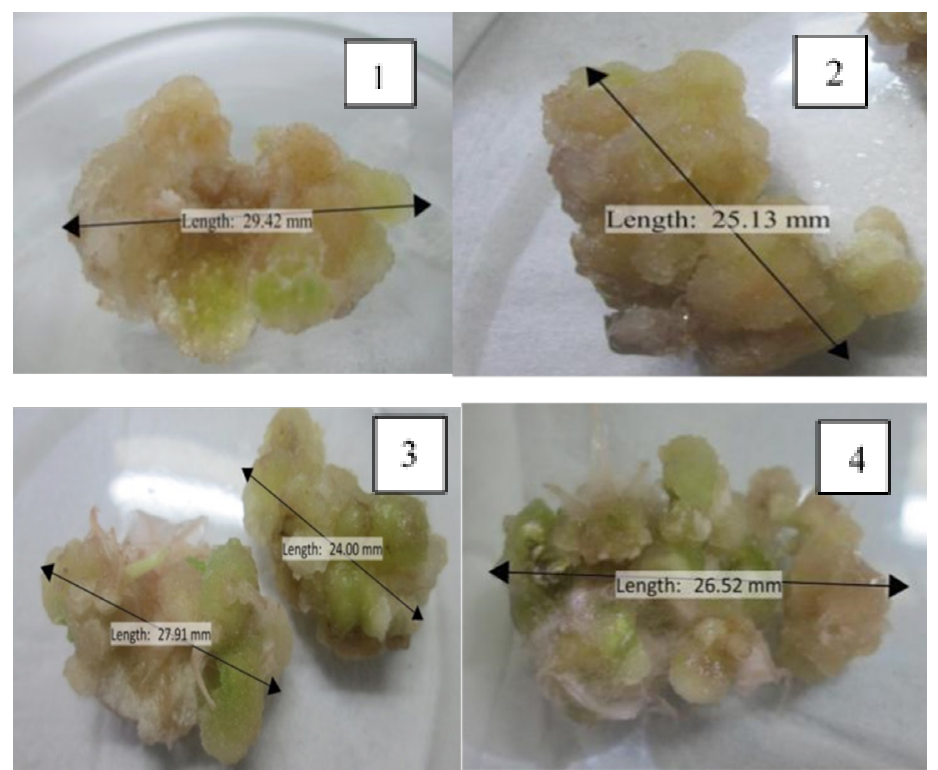

Figure 4. Color of callus Lycopersicon esculentum on 50-day old. Remarks 1: Treatment without subculture, 2: once subculture, 3: twice subculture 4: thrice subculture

The resulting callus color in this study looked uneven so that the callus color visualization was taken from the dominant color of the callus and followed by additional colors that appear. During the initial development, the white callus then turned yellowish and at the end of the observation, the green color appeared in certain parts. According to Isah (2019), the formation of green parts in the callus is the beginning of morphogenesis, this is in line with the formation of shoots. Nurchayati et al. (2018) previously reported that the combination of BAP $6 \times 10^{-6} \mathrm{M}$ with NAA $10^{-5}$ Indriani et al.
M produces compact green Datura metel L. callus with meristemoid tissue on part of the surface.

\section{Callus Development}

Callus development is a parameter used to observe the effect of subculture frequency on the possibility of cell differentiation in callus into recognizable organs. The organs observed were root and shoot. The existence of roots for callus growth plays a very important role because the roots can optimize the absorption of nutrients in the planting medium. The 


\section{JURNAL BIDDJATI}

http://journal.uinsgd.ac.id/index.php/biodjati

emergence of shoots marks a multiplication process in the planted callus.

The results of root development in callus presented in Table 3 and Figure 4. Almost all treatments in callus are able to produce root growth, but the number of roots that appear is different in each treatment. Treatment without subculture produced short roots with an average of one root observed. It might due to the low nutrient content that unable to support the callus to grow roots in large numbers. Subculture treatment once produced short roots with an average of 2 number of roots appeared. This amount was more than the treatment without subculture but less than the twice and thrice subculture treatment. Twice and thrice subculture treatment resulted in an average of 10 and 8 roots respectively. This is due to the callus received an adequate supply of nutrients. Based on these data, the frequency treatment of subcultures significantly influenced development (morphogenesis).

The results of the twice subculture treatment showed a higher number of roots compared to the thrice subculture treatment. This could be due to a shorter incubation period of the thrice subculture treatment than the twice subculture. The shorter incubation period causes the callus unable to absorb nutrients optimally due to the need for re-adaptation after subculture treatment.

The formation of roots is stimulated by the auxin hormone. A hormone that is given periodically through subcultures stimulates root growth and development. According to Nick \& Opatrný (2014), Yusnita et al. (2018) the active auxins used for root formation are Naphthalene Acetic Acid (NAA) and Indol Butyric Acid (IBA), both of which form roots when used at low concentrations. The type of root system produced also depends on the growth regulator used. Phenoxy acids at 2,4-D and 2,4,5-T produce a large, thick and sturdy root system. The IBA hormone produces a strong fibrous root system. Rafiq et al. (2007) reported that maximum root induction and proliferation was found in Stevia rebaudiana culture by supplemented with $0.5 \mathrm{mg} / \mathrm{L} \mathrm{NAA}$ into the medium.
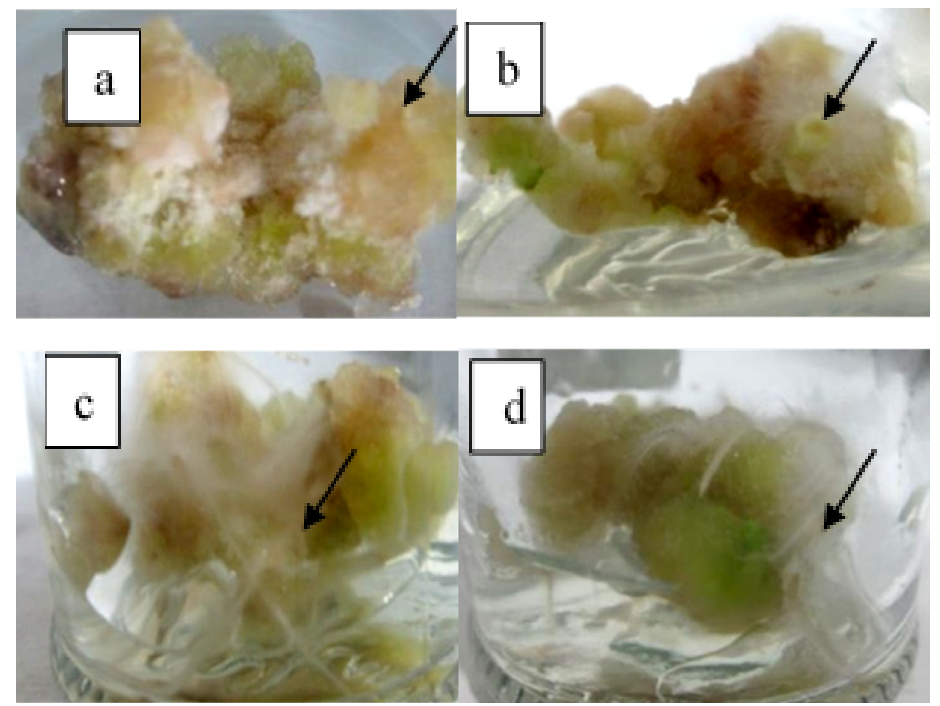

Figure 5. Roots formation in tomato callus. a) without subculture, b) once subculture, c) twice subculture, d) thrice subculture. 


\section{JURNAL BIDDJATI}

http://journal.uinsgd.ac.id/index.php/biodjati

The shoot is a part of the plant obtained from vegetative growth, which grows in order to generate the offspring on a plant. The formation of shoots shows the success of the regeneration of inoculated explants on tissue culture media. Callus resulting from hypocotyl explants of tomatoes can differentiate to form buds. However, in this study, not all callus were able to differentiate into shoots which due to subculture treatment. Data on the emergence of shoots on callus from tomato hypocotyl explants presented in Table 3.

The shoots appear only in callus on twice and thrice subculture treatment (Table 3). This shows the subculture frequency affected the development (morphogenesis) of cells from the callus into shoots. The growth of shoots is driven by hormones available in the media. According to Sitinjak et al. (2016) and Muliati (2017), the use of BAP at the right concentration is very effective in stimulating callus and shoot multiplication because the addition of BAP into in vitro propagation media plays an active role in organogenesis naturally. The BAP growth regulator is one of the cytokinin groups that can stimulate and induce callus, but the type and concentration of growth regulator depend on the type of plant. The similar research by Kumlay \& Ercisli (2015) and Rizal et al. (2017), reported that the addition of different BAP concentrations to the media would affect the induction of shoots in vitro.

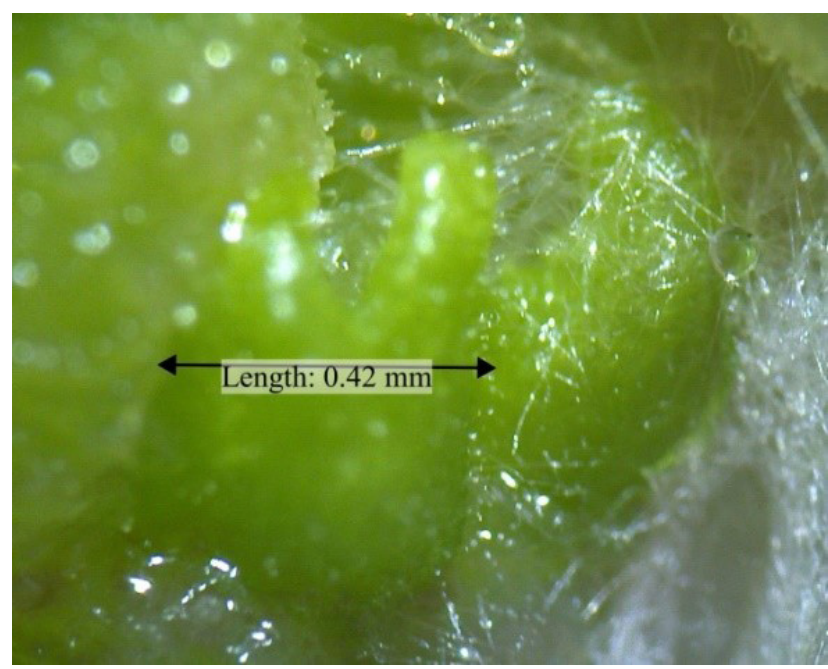

Figure 6. Shoots formation after subculture treatments

The shoots shown in the picture (Figure 6) are bright green shoots and are found in the frequency subculture treatment of twice and thrice. The number of shoots that appeared in each treatment was one. The emergence of shoots indicates the beginning of the organogenesis phase. The growth of shoots can be stimulated by the hormone cytokinin which is added to the media. Research Karyanti et al. (2014) reported the addition of BA $1 \mathrm{mg} / \mathrm{L}$ in callus Jatropha curcas L. which was 10 weeks old produced $100 \%$ callus sprouts on solid media within 4 weeks after subculture. Furthermore, in the study of Karlianda et al. (2010) and Wahyuni et al. (2020) stated that the combination treatment of $0.1 \mathrm{mg} / \mathrm{L}$ NAA $+2.5 \mathrm{mg} / \mathrm{L}$ BAP was the best treatment that produced the highest number of shoots compared to other treatments in the agarwood callus subculture (Aquilaria malaccensis Lamk). 


\section{JURNAL BIDDJATI}

http://journal.uinsgd.ac.id/index.php/biodjati

\section{ACKNOWLEDGEMENTS}

The author would like to thank the Faculty of Science and Mathematic Universitas Diponegoro for PNPB funding research 2018: 1754 F/UN7.5.8/PG/2018.

\section{REFERENCES}

Asmono, S. L. \& Sari, V. K. (2016). Induksi Kalus dari Beberapa Kultivar Tanaman Kentang (Solanum tuberosum L.) Dataran Medium Secara in vitro Menggunakan Variasi Konsentrasi 2,4-D. Jurnal Ilmiah Inovasi, 16(2), 116-121.

Baldi, A. \& Dixit, V. (2008). Enhanced Artemisinin Production by Cell Cultures of Artemisia annua. Current Trends in Biotechnology and Pharmacy, 2(2), 341-389.

Benítez-García, I., Vanegas-Espinoza, P. E., Meléndez-Martínez, A. J., Heredia, F. J., Paredes-López, O. \& Del Villar-Martínez, A. A. (2014). Callus Culture Development of Two Varieties of Tagetes erecta and Carotenoid Production. Electronic Journal of Biotechnology, 17(3), 107-113.

Grzyb, M., Kalandyk, A., Waligórski, P. \& Mikuła, A. (2017). The Content of Endogenous Hormones and Sugars in the Process of Early Somatic Embryogenesis in the Tree Fern Cyathea delgadii Sternb. Plant Cell, Tissue and Organ Culture, 129(3), 387-397.

Hariyati, M., Bachtiar, I. \& Sedijani, P. (2016). Induksi Kalus Tanaman Krisan (Chrysanthemum morifolium) dengan Pemberian Benzil Amino Purin (BAP) dan Dichlorofenoksi Acetil Acid (2,4 D). Jurnal Penelitian Pendidikan IPA, 2(1), 89-96.

Hegazi, G. A., Zayed, M. S., Salem, H. M. \&
Ibrahim, W. M. (2014). Effect of Explant Type and Sequential Subcultures on in vitro Multiple Shoots Formation of Jojoba. Journal of Applied Environmental and Biological Sciences, 4(4), 214-222.

Ikeuchi, M., Sugimoto, K. \& Iwase, A. (2013). Plant Callus: Mechanisms of Induction and Repression. Plant Cell, 25(9), 3159-3173.

Ikhtimami. (2012). Pengaruh Periode Subkultur Terhadap Kadar Saponin Akar Rambut Tanaman Ginseng Jawa (Talinum paniculatum Gaertn.). Skripsi.

Isah, T. (2019). De novo in vitro Shoot Morphogenesis from Shoot Tip-induced Callus Cultures of Gymnema sylvestre (Retz.) R.Br. ex Sm. Biological Research, 52(3), 1-8.

Javanmardi, J. \& Kubota, C. (2006). Variation of Lycopene, Antioxidant Activity, Total Soluble Solids and Weight Loss of Tomato During Postharvest Storage. Postharvest Biology and Technology, 41(2), 151-155.

Karlianda, N., Wulandari, R. S. \& Mariani, Y. (2010). Pengaruh NAA dan BAP Terhadap Pengaruh NAA dan BAP Terhadap Perkembangan Subkultur Gaharu (Aquilaria malaccensis Lamk.) (The Influence of NAA and BAP to the Development of Agarwood (Aquilaria malaccensis Lamk.) Subcultures). Retrieved from http:// download.portalgaruda.org/article. php article $=32761 \&$ val $=2332 \&$ title $=-$ PENGARUH NAA DAN BAP TERHADAP PERKEMBANGAN SUBKULTUR GAHARU (Aquilaria malaccensis Lamk.).

Karyanti, J. \& Tajuddin, T. (2014). Kemampuan Tumbuh Eksplan Jatropha curcas L. pada Media in vitro yang Mengandung 


\section{JURNAL BIDDJATI}

http://journal.uinsgd.ac.id/index.php/biodjati

Hormon IBA dan BA. Jurnal Bioteknologi \& Biosains Indonesia (JBBI), $1(1), 1-8$.

Krishna, H., Alizadeh, M., Singh, D., Singh, U., Chauhan, N., Eftekhari, M. \& Sadh, R. K. (2016). Somaclonal Variations and their Applications in Horticultural Crops Improvement. 3 Biotech, 6(1), $1-18$.

Lipavská, H., Mašková, P. \& Vojvodová, P. (2011). Regulatory Dephosphorylation of CDK at G2/M in Plants: Yeast Mitotic Phosphatase cdc25 Induces Cytokinin-like Effects in Transgenic Tobacco Morphogenesis. Annals of Botany, 107(7), 1071-1086.

Maemunah, Yusuf, R., Samudin, S., Yusran, Hawalina \& Rini, N. S. (2019). Initiation of Onion Callus (Allium wakegiaraki) Varieties of Lembah Palu at Various Light Intensities. IOP Conference Series: Earth and Environmental Science, 361(1).

Majda, M. \& Robert, S. (2018). The Role of Auxin in Cell Wall Expansion. International Journal of Molecular Sciences, 19(4), 1-21.

Maleta, H. S., Indrawati, R., Limantara, L. \& Brotosudarmo, T. H. P. (2018). Ragam Metode Ekstraksi Karotenoid dari Sumber Tumbuhan dalam Dekade Terakhir (Telaah Literatur). Jurnal Rekayasa Kimia \& Lingkungan, 13(1), 40-50.

Ming, N. J., Mostafiz, S. B., Johon, N. S., Zulkifli, N. S. A. \& Wagiran, A. (2019). Combination of Plant Growth Regulators, Maltose, and Partial Desiccation Treatment Enhance Somatic Embryogenesis in Selected Malaysian Rice Cultivar. Plants, 8(6), 1-15.

Muliati, T. Nurhidayah, N. (2017). Media on the in vitro Development Sansevieria macrophylla. Jom Faperta, 4(1), 1-13.

Naghmouchi, S., Khouja, M. L., Rejeb, M. N. \& Boussaid, M. (2008). Effect of Growth Regulators and Explant Origin on in vitro Propagation of Ceratonia siliqua L. via Cuttings. Biotechnology, Agronomy and Society and Environment, 12(3), 251-258.

Nick, P. \& Opatrný, Z. (2014). Preface. Plant Cell Monographs, 22.

Norshazila, S., Othman, R., Jaswir, I. \& Yumi Zuhanis, H. H. (2017). Effect of Abiotic Stress on Carotenoids Accumulation in Pumpkin Plants Under Light and Dark Conditions. International Food Research Journal, 24(Suppl.), 387-394.

Noviati. (2014). Respon Pertumbuhan dan Produksi Senyawa Antioksidan pada Kalus Hibiscus sabdarifa L. dari Eksplan yang Berbeda Secara in vitro. Jurnal Sains dan Matematika, 22(1), 25-29.

Nurchayati, Y., Santosa, Nugroho, L. H. \& Indrianto, A. (2018). Buletin Anatomi dan Fisiologi Volume 3 Nomor 1 Februari 2018 Penggunaan Kinetin, Asam Naftalen Asetat, dan Benzil Adenin dalam Induksi Kalus Kecubung (Datura metel L .) Secara In Vitro Use of Kinetin, Naphthalene Acetate Acid, and Benzyl Adenine in I. 3.

Olusegun, A., Makun, H. A., Ogara, I. M., Edema, M., Idahor, K. O., Oluwabamiwo, B. F. \& Eshiett, M. E. (2012). We are IntechOpen, the World's leading Publisher of Open Access books Built by scientists, for scientists TOP $1 \%$. Intech, i(tourism), 38.

Orbán, N., Boldizsár, I., Szucs, Z. \& Dános, B. (2008). Influence of Different Elicitors on the Synthesis of Anthraquinone Derivatives in Rubia tinctorum L. Cell Suspension Cultures. Dyes and Pig- 


\section{JURNAL BIDDJATI}

http://journal.uinsgd.ac.id/index.php/biodjati

ments, 77(1), 249-257.

Osman, H. A., Taha, H. S., Youssef, M. M. A., El-Gindi, A. Y., Ameen, H. H. \& Lashein, A. M. S. (2012). Establishment of Calli Cultures from Different Explants of Tagetes erecta and T. Patula. Journal of Applied Sciences Research, 8(7), 3850-3854.

Purnamaningsih, R., \& Ashrina, M. (2011). Pengaruh BAP dan NAA Terhadap Induksi Kalus dan Kandungan Artemisin dari Artemisia annua L. 1 [The Effect of BAP and NAA on Callus Induction and Artemisinin Content of Artemisia annua L.]. Berita Biologi, 10(4), 481489.

Rafiq, M., Dahot, M. U., Mangrio, S. M., Naqvi, H. A., Iqbal, A. \& Qarshi, A. (2007). In vitro Clonal Propagation and Biochemical Analysis of Field Established Stevia rebaudiana Bertoni. Pakistan Journal of Botany, 39(7), 2467-2474.

Ravi, M., De, S. L., Azharuddin, S. \& Paul S. F. D. (2010). The Beneficial Effects of Spirulina Focusing on its Immunomodulatory and Antioxidant Properties. Nutrition and Dietary Supplements, 2, 73-83

Rivai, R. R., Husni, A. \& Purwito, A. (2014). Induksi Kalus dan Embrio Somatik Tanaman Jambu Biji Merah (Psidium guajava L.). Buletin Agrohorti, 2(1), 49-58.

Sari. (2019). Induction and Growth of Endosperm Callus of Rimau Gerga Lebong (RGL) Citrus on Several Media Composition. Akta Agrosia, 11(2), 56-62.

Sari, D. A., Slameto \& Restanto, D. P. (2014). Induksi Tunas Kentang (Solanum tuberosum L.) menggunakan BAP (Benzil Amino Purine). Berkala Ilmiah Pertanian, $\mathrm{x}, 1-4$.
Setyorini. (2018). Pengaruh Pemberian PEG (Polyethylen Glycol) 6000 (Foeniculum vulgare Mill.). Skripsi. Jurusan Biologi Fakultas Sains dan TeknologiUniversitas Islam Negeri Maulana Malik Ibrahim Malang 2018.

Shah, M. R. \& George, I. A. (2019). Increased Biomass and Pigment Production from Cassia alata L. Callus Cultures and their Potential as a Textile Dye. Industrial Crops and Products, 128, , 346353.

Sitinjak, M. A. Isda, M. N. \& Fatonah, S. (2016). Induksi Kalus dari Eksplan Daun In Vitro Keladi Tikus (Typhonium sp.) dengan Perlakuan 2,4-D dan Kinetin. Al-Kauniyah Jurnal Biologi, 8(1), 32-39.

Sugiyarto, L. \& Kuswandi, P. (2014). Pengaruh 2, 4-Diklorofenoksiasetat (2, 4-D) dan Benzyl Aminopurin (BAP) Terhadap Pertumbuhan Kalus Daun Binahong (Anredera). Jurnal Penelitian Saintek, 19(1), 23-30.

Wahyuni, A., Satria, B. \& Zainal, A. (2020). Induksi Kalus Gaharu dengan NAA dan BAP Secara In Vitro. Agrosains: Jurnal Penelitian Agronomi, 22(1), 39-44.

Wulansari, A., Purwito, A., Husni, A. \& Sudarmonowati, E. (2015). Kemampuan Regenerasi Kalus Embriogenik Asal Nuselus Jeruk Siam serta Variasi Fenotipe Tunas Regeneran. Prosiding Seminar Nasional Masyarakat Biodiversitas Indonesia, 1(1), 97-104. 